\title{
Nutrition of rice as influenced by reclamation techniques for acid sulfate soil in Cox's Bazar
}

\author{
Md. H. R. Khan
}

Department of Soil, Water and Environment, University of Dhaka, Dhaka 1000, Bangladesh

\begin{abstract}
A field experiment was conducted for the reclamation of a Cheringa hot spot of acid sulfate soil manipulated by flash leaching followed by basic slag (BS; $\mathrm{BS}_{10}$ and $\mathrm{BS}_{20}$ : basic slag at 10 and $20 \mathrm{t} \mathrm{ha}^{-1}$ ), aggregate size (A; $\mathrm{A}_{20}$ and $\mathrm{A}_{30}$ : aggregate sizes of soil less than 20 and 20-30 mm) treatments under two different techniques (Tech 1: pyrite layer at top, jarosite layer at middle and top soil at the bottom of ridge; Tech 2: top soil at top, pyrite layer at middle and jarosite layer at the bottom of ridge). Nutritional responses to two cultivars of rice with the treatments were evaluated. The initial soil had very low $\mathrm{pH}\left(\mathrm{H}_{2} \mathrm{O}\right) ; 3.4$, and high EC; $1.6 \mathrm{~m} \mathrm{~S}^{-1}$, and pyrite content, $76 \mathrm{~g} \mathrm{~kg}^{-1}$. Magnesium content (5.38 c mol kg-1) of the soil was about 3 fold than that of $\mathrm{Ca}\left(1.71 \mathrm{c} \mathrm{mol} \mathrm{kg}^{-1}\right)$, and $\mathrm{Al}$ content $\left(9.22 \mathrm{c} \mathrm{mol} \mathrm{kg}^{-1}\right)$ was at a highly toxic level. The average soil data of all the treatments, except for the control plots after harvesting of rice were increased by 1.5 units for soil $\mathrm{pH}$ and 12 to $463 \%$ for the contents of $\mathrm{N}, \mathrm{P}, \mathrm{Ca}$ and $\mathrm{Mg}$, while the concentrations of $\mathrm{Fe}, \mathrm{Al}, \mathrm{Na}, \mathrm{Cl}^{-}$and $\mathrm{SO}_{4}^{2-}$ decreased by 27 to $93 \%$ compared with the initial soil.

The highest $\mathrm{N}, \mathrm{P}, \mathrm{K}, \mathrm{Ca}$, and $\mathrm{Mg}$ contents in both the $\mathrm{BR} 14$ and Pizam rice shoots at maturity were obtained by the $\mathrm{A}_{20} \mathrm{BS}_{30}$ followed by $\mathrm{A}_{20} \mathrm{BS}_{20} \geq \mathrm{A}_{30} \mathrm{BS}_{30}$ treatments. The other treatments also resulted in a significant $(\mathrm{p} \leq 0.05)$ improved performance on plant nutrition compared with the control. The local Pizam exhibited the best responses under the Tech 2 in order of these nutrient uptakes. Sulfur content in the rice plants on control plots was high (1.8-2.1 $\left.\mathrm{g} \mathrm{kg}^{-1}\right)$ but it decreased significantly by the different treatments.
\end{abstract}

Keywords: Acid sulfate soil; Aggregate size; Basic slag; Nutrition of rice plant; Pyrite and Jarosite layers

\section{Introduction}

The availability of land for growing crops is limited; it may become inevitable to utilize marginal/problem soils and extend acreage under crop production to feed the hungry people. Among the problems, acid sulfate soils (ASSs) have been lasting severe environmental degradation, which affect some $100 \mathrm{M}$ ha of land world-wide of which about $0.7 \mathrm{M}$ ha are located in inundated coastal areas in Bangladesh where crop production is very low; some where the lands are unproductive though the soils have high agricultural potential (Van Mensvoort and Dent, 1998; Khan, 2000). The ASSs generate $\mathrm{H}_{2} \mathrm{SO}_{4}$ that brings their $\mathrm{pH}$ from 6-7 to below 4, and sometimes to as low as 2 . This acid leaks into drainage and floodwaters, corrodes steel and concrete, and attacks clay liberating elements in toxic concentrations (Khan et al., 2002).

Conventional reclamation of ASSs through liming and flash-leaching is not sustainable (Khan et al., 1994) because soil acidity produced by $1 \%$ oxidizable sulfur requires about $30 \mathrm{t}$ of $\mathrm{CaCO}_{3} \mathrm{ha}^{-1}$ (Van Breemen, 1993). Usually ASSs contain $1-5 \%$ oxidizable sulfur and the use of more than $10 \mathrm{t}$ lime $\mathrm{ha}^{-1}$ showed an antagonistic effect on micronutrient levels as well as on the balance of basic cations in plants (Khan et al., 1996). Neutralization of ASSs with lime and/or leaching leads to the deterioration of the soils, related ecosystems, and to permanent soil acidification (Khan and Adachi, 1999). Dent (1986) reported that basic slag from steel industry was effective in reducing soil acidity and also economical if available locally. Khan et al., (1994, 2006) reported that the application of BS in ASSs significantly increased soil $\mathrm{pH}, \mathrm{Ca}$ and $\mathrm{Mg}$ with an associated decrease in $\mathrm{Na}, \mathrm{S}, \mathrm{Fe}$ and $\mathrm{Al}$ concentrations over time. Basic slag as a byproduct from the steel industry in Bangladesh can be collected almost free of charge. This BS had a very high $\mathrm{pH}$ of 9.6 and contained $20.8 \% \mathrm{Ca}, 9.8 \% \mathrm{Mg}$, and $12.8 \% \mathrm{SiO}_{2}$ (Khan et al., 2006). The previous techniques of plain-ridge-ditch or raised beds used for the reclamation of ASSs in Vietnam, Thailand, Indonesia and the Netherlands (Dost and van Breemen, 1982; Dent, 1986; Dent and Mensvoort, 1993), where pyritic materials were taken from the sub-soils, were covered by non-pyritic top-soils and followed by flash-leaching by rain or irrigation. These

\footnotetext{
* Corresponding author e-mail: duharun@yahoo.com
} 
techniques have not had much success and were not sustainable, which might be due to the lack of (i) proper oxidation of pyritic materials, (ii) neutralization of acidity, (iii) recovery of basic cations lost during leaching, (iv) mitigation measures against environmental threats arising from the acidity and toxic elements laden during reclamation. But in the present modified-plain-ridge-ditch-techniques, where different sizes of aggregates were used for proper oxidation of pyritic materials and BS for the neutralization (slit was used for in-situ neutralization to a deeper depth) as well as recovery of the basic cations lost during leaching; placement of pyritic materials in different patterns was considered on the basis of tidal influences and economic conditions of farmers. These integrated systems will not only reclaim the ASSs but will also safeguard the associated environment from the threats of acid drainage wastes.

Successful reclamation of the ASSs may result in the development of productive fields for crop growth. While poor soil reclamation may lead to the creation of unfavorable soil conditions for crop growth and formation of actual ASSs, the real problem is in the coastal tidal flat plain areas (Khan et al., 2007). Against this background, the objective of the present field study was to evaluate the nutrition of rice as influenced by basic slag, aggregate size treatments under Modified-Plain-Ridge-Ditch Techniques for the reclamation of acid sulfate soil.

\section{Materials and methods}

\section{Experimental site and condition}

A field experiment was conducted in a fallow land at Cheringa hot spot of ASS in the coastal old mangrove floodplain area in the Cox's Bazar district of Bangladesh. The lands are usually inundated by saline seawater tides of about 0.2 to $0.6 \mathrm{~m}$ high (about 180 times a year). On the basis of tidal conditions, the height of the ridges constructed on plain land under the techniques used was $0.6 \mathrm{~m}$. But during the experiment, the study site was protected from natural tides by a dike (1.5 m high) around the experimental site. The site enjoy 'tropical monsoon climate', has three main seasons, namely, the monsoon or rainy season, the dry or winter season and the pre-monsoon or summer season. This area in Bangladesh was once occupied for centuries by dense mangrove forest. Now about $95 \%$ of the areas have been cleared for agricultural cultivation. As a result, the potential ASSs have become actual ASSs with very poor yields or somewhere unproductive. Eight series of such ASSs were studied in the field on the basis of land type, land use, hydrological conditions and depths of acid forming layers. Among these, the Cheringa ASS at Sarisabari (Fig. 1) was selected for further studies in relation to the nutrition of rice.

\section{Experimental design and field preparation}

The experiment was set up in a completely randomized block design with three replications. There was an approximately $1.5 \mathrm{~m}$ wide and $1.0 \mathrm{~m}$ deep drain around the experimental field, about a 0.5 and $0.3 \mathrm{~m}$ boundary around each main plot and subplot, respectively for protecting the individual plot from the contamination of the treatments. The field of about 0.75 ha was divided into 12 main plots each having $10 \times 5 \mathrm{~m}^{2}$ sizes. In each main plot of plain or ridge, there were 6 subplots of $1 \times 1 \mathrm{~m}^{2}$ but there was no subplot in the ditch, which was about $10 \times 5 \mathrm{~m}^{2}$ wide and 0.4 to $0.6 \mathrm{~m}$ deep. The subplots of $1 \times 1 \mathrm{~m}^{2}$ were then used for individual treatment. These plots were irrigated mainly by using rainwater (yearly rainfall $>4000 \mathrm{~mm}$ ) collected from the local rain-fed channels through the irrigation pump. Pond water was also used for irrigation during the dry period. Saline water intrusion and drainage water were controlled through dikes and flap gates. Basic slag was collected from a steel industry and then grounded to less than $1 \mathrm{~mm}$ sizes in order to apply in the field. The rates of $\mathrm{BS}_{10}$ and $\mathrm{BS}_{20}$ (basic slag at 10 and 20 $\mathrm{t} \mathrm{ha}^{-1}$ ) were incorporated into the topsoil (depth: 0-0.2 $\mathrm{m}$ ) by broadcasting during ploughing. For in-situ neutralization of acidity arising from jarosite and pyrite layers in the modified-plain-ridge-ditch techniques (Fig. 2), the same doses of BS were incorporated into the subsoil (0.2-0.4 $\mathrm{m}$ ) by using a soil slitter ( $5 \mathrm{~cm}$ diameter) at every $0.2 \mathrm{~m}$ of distance.

\section{Modified-Plain-Ridge-Ditch Techniques}

Plain: The area of each plain plot (flood plain land) was $10 \times 5$ $\mathrm{m}^{2}$ and the particle size of the soil in the plain plot was grounded manually into two aggregate sizes of about less than 20 , and 20 to $30 \mathrm{~mm}\left(\mathrm{~A}_{20}\right.$ and $\left.\mathrm{A}_{30}\right)$. The grounded soils were then processed under the sun and open air for maximum oxidation within 2 days. The plain land was considered to reclaim by the application of flash-leaching (5-7 times of washing within a week: till the $\mathrm{pH}$ becomes $>4.5$ and lower ECe values) followed by the application of BS treatments $\left(\mathrm{BS}_{10}\right.$ and $\mathrm{BS}_{20}$ as suggested by Khan, 2002). The drainage waters from the plain plots under the Modified-Plain-Ridge-Ditch techniques were disposed to the nearby ditches where the water was treated by BS as required to raise the water $\mathrm{pH}$ to 5.5 .

Ridge: The ridge means a raised bed of about $0.6 \mathrm{~m}$ soil, stacked upon flood plain soil (plain land), which was made by raising different layers of soil through excavation and arranged as shown in the Fig. 2 (Tech 1 and Tech 2). These $0.6 \mathrm{~m}$ high beds were constructed to facilitate leaching of acidity and salinity from the soil. The area of the top of each ridge was similar to that of the plain plot. Particle sizes of the bed materials were grounded manually into two aggregate sizes of $A_{20}$ and $A_{30}$ (aggregate sizes of soil less than 20 and 


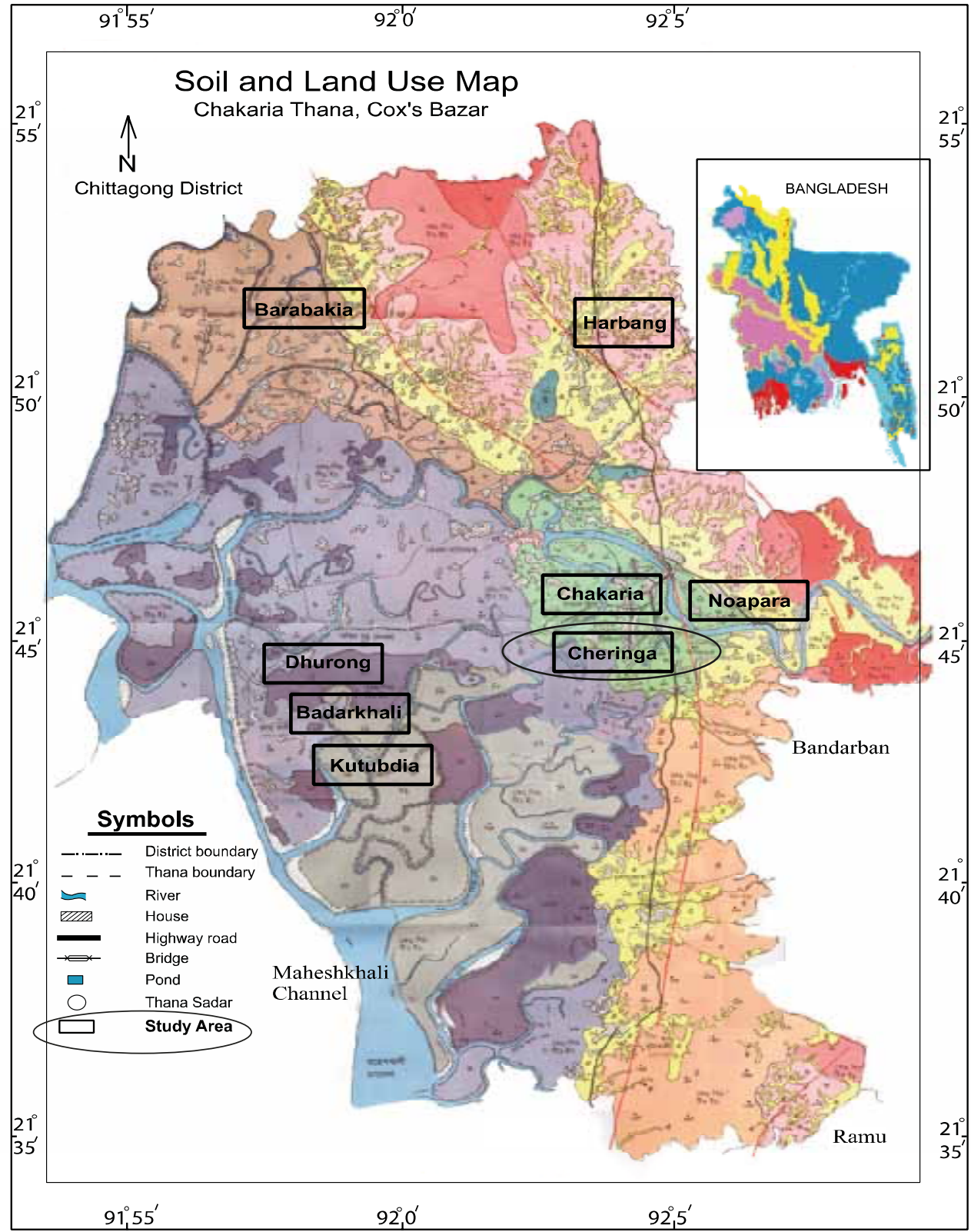

Fig. 1. Site map of the study area (oval shape marked) in Cox's Bazar of Bangladesh.

20-30 mm). These smaller sizes of aggregates were considered in order to understand the effects of oxidation of sulfidic materials (pyrite/jarosite) and their quick drainage from this heavy-textured ASS. Each plot on the ridge of the different techniques was brought into flash-leaching followed by the application of BS treatments as practiced for the plain plot. The drainage water into the nearby ditches was treated by $\mathrm{BS}$ to raise the water $\mathrm{pH}$ till 5.5. The arrangements of soil layers in different techniques were as follows:
Technique 1: The top layer (surface soil) was extended to about a $0.2 \mathrm{~m}$ thick layer ( $1^{\text {st }}$ layer: $0-0.2 \mathrm{~m}$ ) primarily onto the adjacent plots and was grounded into different aggregate sizes $\left(\mathrm{A}_{20}\right.$ and $\left.\mathrm{A}_{30}\right)$ as per treatment requirement and was kept open to air for oxidation within 2 days. Then, the second layer (0.2-0.4 m layer: sub surface soil with jarosite material) was extended to about a $0.2 \mathrm{~m}$ thick layer onto that processed first layer. The soil of the second layer was also grounded to the desired sizes of aggregates and kept for oxidation within 2 days. Finally, the third layer (0.4-0.6 m layer: deeper soil 
containing pyrite material) was placed at the top of the previously stacked layers. This third layer was also considered for the preparation of different sizes of aggregates and for the oxidation of 2 days. After that, the prepared $0.6 \mathrm{~m}$ raised beds were taken under extensive leaching (5-7 times washing within a week) with rain and pond water. Thereafter, the top soil of the ridge was subjected to the different rates of BS application as per treatments designed for the experiment.

Technique 2: The preparation and processing of land such as aggregate size, duration of oxidation through air drying and experimental treatments were similar to those stated for Tech 1, except for the arrangement of soil layers. In Tech 2, within the ridge (raised bed of $0.6 \mathrm{~m}$ ), the arrangement of soil layers was like the jarosite layer was placed at the bottom ( $3^{\text {rd }}$ layer: $0.4-0.6 \mathrm{~m})$, then the pyrite layer in the middle $\left(2^{\text {nd }}\right.$ layer: $0.2-0.4 \mathrm{~m})$ followed by the surface soil onto the top $(0-0.2 \mathrm{~m})$ of the ridge.

Ditch: Adjacent to each ridge, there was a ditch of about $10 \mathrm{x}$ $5 \mathrm{~m}^{2}$ having a depth of about 0.4 to $0.6 \mathrm{~m}$ attributed to the excavation of soil for the preparation of ridges. These ditches were constructed as a reservoir of acid drainage waters, where these acidic waters were neutralized by the use of BS during dry season. But during rainy season, these acidic wastes were automatically diluted by rain and/or controlled runoff waters.

Two aman varieties of rice (high yielding variety - HYV BR 14 and local Pizam) were planted in the Cheringa ASS. The top soil (0-0.2 $\mathrm{m}$ ) in each plot (plain and ridge) was fertilized with $\mathrm{N}, \mathrm{P}$ and $\mathrm{K}$ at the rates of 100,80 and $60 \mathrm{~kg} \mathrm{ha}^{-1}$ as urea, triple super phosphate (TSP) and muriate of potash (MP), respectively as a basal dose. All the TSP and MP and one-third urea were applied just one day prior to transplantation whereas the rest of the two-thirds of urea were applied as top dressing two times after 30 and 60 days of transplantation. The plots were allowed to receive natural rain and pond waters whenever necessary to maintain favorable conditions (maximum saturated to field moist condition) for rice. Thirty day-old healthy and uniform seedlings were transplanted at the rate of four plants per hill. The distances between the hills were $15 \mathrm{~cm}$. Pests were controlled by the use of the insecticide, 'Nogos' whenever it was required.

Soil analysis: The bulk samples obtained from the soil were stored for a couple of days under field-moist conditions (by putting the soil samples into polyethylene bags in an air-tight box) just prior to laboratory analysis, when the sub-samples were air-dried and crushed to $2 \mathrm{~mm}$ before analyses. After treatment with $1 \mathrm{M} \mathrm{CH}_{3} \mathrm{COONH}_{4}(\mathrm{pH} \mathrm{5.0)}$ and with $30 \%$ $\mathrm{H}_{2} \mathrm{O}_{2}$ to remove free salts and organic matter, respectively, particle size distribution was determined by the pipette method (Day, 1965). Soil pH was measured for the oven dried soil in soil-water (1:2.5) suspension using a Corning $\mathrm{pH}$ meter Model-7 as described by Jackson (1973). For saturation extract of soil, the electrical conductivity (Richards, 1954), water soluble $\mathrm{Na}^{+}$and $\mathrm{K}^{+}$(flame photometry: Black, 1965), water soluble $\mathrm{SO}_{4}^{2-}$ and $\mathrm{Cl}^{-}$ contents (Jackson, 1973); $\mathrm{Ca}^{2+}, \mathrm{Mg}^{2+}, \mathrm{Fe}^{3+}$ and $\mathrm{Al}^{3+}$ (atomic absorption spectrometry - AAS: Hesse, 1971) were determined. Organic matter content was determined (Nelson and Sommers, 1982) by wet combustion with $\mathrm{K}_{2} \mathrm{Cr}_{2} \mathrm{O}_{7}$. Available N (1.3M KCl extraction; Jackson, 1973), available $\mathrm{P}\left(0.002 \mathrm{~N} \mathrm{H}_{2} \mathrm{SO}_{4}, \mathrm{pH} 3\right.$ extraction, Olsen et al. 1954) were determined. Cation exchange capacity was determined by saturation with $1 \mathrm{M} \mathrm{CH}_{3} \mathrm{COONH}_{4}(\mathrm{pH} 7.0)$, ethanol washing, $\mathrm{NH}_{4}{ }^{+}$displacement with acidified $10 \% \mathrm{NaCl}$, and subsequent analysis by steam distillation (Kjeldhal method: Chapman, 1965). Exchangeable $\mathrm{Na}^{+}, \mathrm{K}^{+}, \mathrm{Ca}^{2+}$ and $\mathrm{Mg}^{2+}$ were extracted with $1 \mathrm{M} \mathrm{CH}_{3} \mathrm{COONH}_{4}(\mathrm{pH}$ 7.0) and determined by flame photometry $\left(\mathrm{Na}^{+}, \mathrm{K}^{+}\right)$and AAS. Exchangeable $\mathrm{Al}^{3+}(1 \mathrm{M} \mathrm{KCl}$; Thomas, 1982) and $\mathrm{Fe}^{3+}\left(1 \mathrm{M} \mathrm{CH}_{3} \mathrm{COONH}_{4}\right.$ : $\mathrm{pH} 4.8$; Black, 1965) were determined by AAS.

Plant analysis: The composite samples of shoot dry matter at maturity were analyzed for $\mathrm{N}$ content by the micro-Kjeldahl method (Jackson, 1973); P content by spectrometry (Jackson, 1973); K content by flame photometry (Black, 1965); S content by turbidometry (Jackson, 1973); $\mathrm{Ca}$ and $\mathrm{Mg}$ contents by AAS (Hesse, 1971) in $\mathrm{HNO}_{3}-\mathrm{HClO}_{4}$ acid (2:1) digest. The level of significance of the different treatments was determined using Duncan's New Multiple Range Test (DMRT) and least significant difference (LSD: Zaman et al., 1982).

\section{Results and discussion}

\section{Pre- and post harvested soils}

The studied Cheringa ASS (depth: 0-0.2 m) showed a silty clay loam texture, initially low $\mathrm{pH}$ of 3.4 , pyrite content of 76 $\mathrm{g} \mathrm{kg}^{-1}$, low base saturation (34\%), high ECe $\left(1.6 \mathrm{~S} \mathrm{~m}^{-1}\right)$, high exchangeable $\mathrm{Fe}^{3+}$ and $\mathrm{Al}^{3+}$ contents of 1.83 and $7.91 \mathrm{c}$ mol $\mathrm{kg}^{-1}$, respectively (Table I). The contents of basic cations in the initial soil were low to medium, while acidic cations were very high in relation to the amounts found elsewhere. The $\mathrm{pH}$ value of the average soil data of all the treatments at post harvesting of rice was found to be increased in $\mathrm{pH}$ from 3.4 to 4.9 , i.e. by 1.5 units higher compared with the control (i.e. initial value), while the ECe value of the soil was decreased to $0.38 \mathrm{~S} \mathrm{~m}^{-1}$ (76\% decreased over control: Table I). The contents of $\mathrm{N}, \mathrm{P}, \mathrm{Ca}$ and $\mathrm{Mg}$ in the average soil data at post harvesting were found to be increased $(\mathrm{IOC}=$ increased over control, i.e. initial value) by 12 to $463 \%$ IOC. The contents of exchangeable $\mathrm{Al}^{3+}, \mathrm{Fe}^{3+}, \mathrm{Na}^{+}, \mathrm{Cl}^{-}$and $\mathrm{SO}_{4}^{2-}$ in the soil were 
Table I. Some selected properties of the initial Cheringa acid sulfate soil (depth: $0-0.2 \mathrm{~m})$ and the average soil (0-0.2 $\mathrm{m}$ ) data of all the treatments at post harvesting of the rice grown under field condition.

\begin{tabular}{|c|c|c|c|}
\hline Soil properties & $\begin{array}{l}\text { Initial } \\
\text { soil }\end{array}$ & $\begin{array}{l}\text { Post harvested } \\
\text { soil }\end{array}$ & $\% \mathrm{IOC} \dagger$ \\
\hline Textural class & & Silty clay loam & \\
\hline Bulk density $\left(\mathrm{Mg} \mathrm{m}^{-3}\right)$ & 1.12 & 1.21 & 8 \\
\hline Moisture at Field Capacity (\%) & 49 & 51 & 4 \\
\hline Soil pH (Dry, 1:2.5) & 3.4 & 4.9 & 44 \\
\hline$\$$ Pyrite content $\left(\mathrm{g} \mathrm{kg}^{-1}\right)$ & 76 & 35 & -54 \\
\hline $\mathrm{ECe}\left(\mathrm{S} \mathrm{m}^{-1}\right)$ & 1.6 & 0.38 & -76 \\
\hline Organic Carbon $\left(\mathrm{g} \mathrm{kg}^{-1}\right)$ & 21.3 & 21.8 & 2 \\
\hline Available $\mathrm{N}\left(1.3 \mathrm{M} \mathrm{KCl}: \mathrm{mM} \mathrm{kg}^{-1}\right)$ & 6.44 & 7.21 & 12 \\
\hline Avail. $\mathrm{P}\left(0.002 \mathrm{~N} \mathrm{H}_{2} \mathrm{SO}_{4}, \mathrm{pH} 3: \mathrm{mM} \mathrm{kg}^{-1}\right)$ & 0.11 & 0.25 & 127 \\
\hline $\mathrm{CEC}\left(1 \mathrm{M} \mathrm{NH}_{4} \mathrm{Cl}: \mathrm{c} \mathrm{mol} \mathrm{kg}{ }^{-1}\right)$ & 19.1 & 19.8 & 4 \\
\hline Base saturation at $\mathrm{pH} 7.0(\%)$ & 34.2 & 77.8 & 127 \\
\hline \multicolumn{4}{|l|}{ Exchangeable cations (1 M KCl) } \\
\hline Sodium (flame photometer: $\mathrm{c} \mathrm{mol} \mathrm{kg}{ }^{-1}$ ) & 3.43 & 2.41 & -30 \\
\hline Potassium (flame photomet.: $\mathrm{c}$ mol kg-1) & 0.36 & 0.76 & 111 \\
\hline Calcium (AAS*: c mol kg-1) & 0.95 & 5.35 & 463 \\
\hline Magnesium (AAS: c mol kg-1) & 1.79 & 6.53 & 265 \\
\hline Aluminum (AAS: c mol kg-1) & 7.91 & 0.53 & -93 \\
\hline Iron (AAS: c mol kg-1) & 1.83 & 0.91 & -50 \\
\hline \multicolumn{4}{|l|}{ Water-soluble ions: } \\
\hline Sodium (flame photometer: $\mathrm{c} \mathrm{mol} \mathrm{kg}{ }^{-1}$ ) & 3.11 & 2.21 & -29 \\
\hline Potassium (flame photomet.: $\mathrm{c} \mathrm{mol} \mathrm{kg-1)}$ & 0.26 & 0.44 & 69 \\
\hline Calcium (AAS $\left.{ }^{\mathscr{J}}: \mathrm{c} \mathrm{mol} \mathrm{kg}^{-1}\right)$ & 0.76 & 3.22 & 324 \\
\hline Magnesium (AAS: c mol kg-1) & 3.59 & 4.87 & 36 \\
\hline Aluminum (AAS: c mol kg-1) & 1.31 & 0.26 & -80 \\
\hline Iron (AAS: $\mathrm{c} \mathrm{mol} \mathrm{kg-1)}$ & 0.43 & 0.57 & 33 \\
\hline Chloride $\left(0.05 \mathrm{~N} \mathrm{AgNO}_{3}: \mathrm{c} \mathrm{mol} \mathrm{kg}^{-1}\right)$ & 3.31 & 2.40 & -27 \\
\hline Sulfate $\left(\mathrm{BaCl}_{2}: \mathrm{c}\right.$ mol kg-1) & 4.06 & 2.63 & -35 \\
\hline
\end{tabular}

found to be decreased by 27 to $93 \%$ IOC (Table I). The results also indicated that the physico-chemical properties of the ASS were strongly influenced by the application of leaching followed by basic slag and aggregate size treatments in different reclamation and management techniques. 


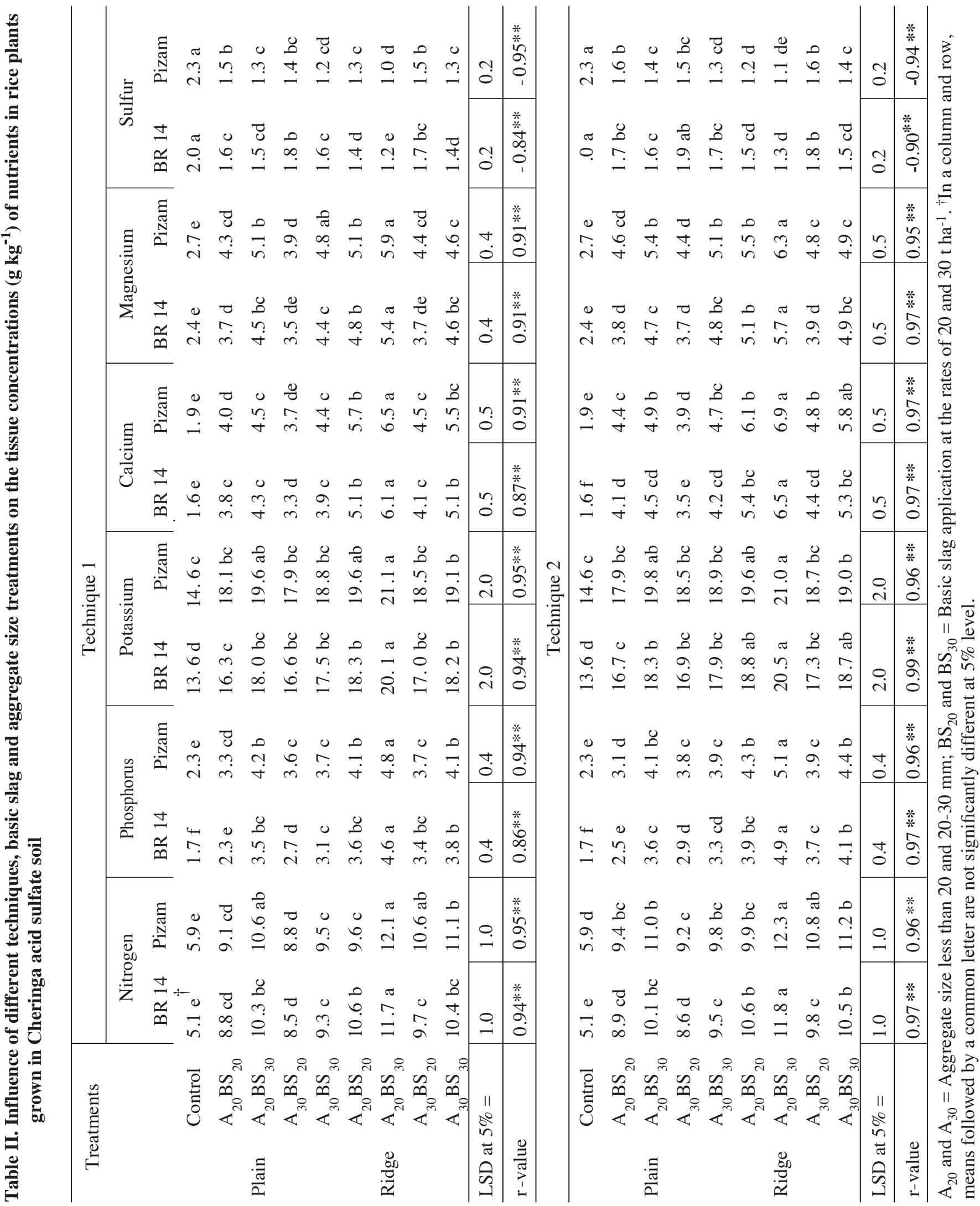



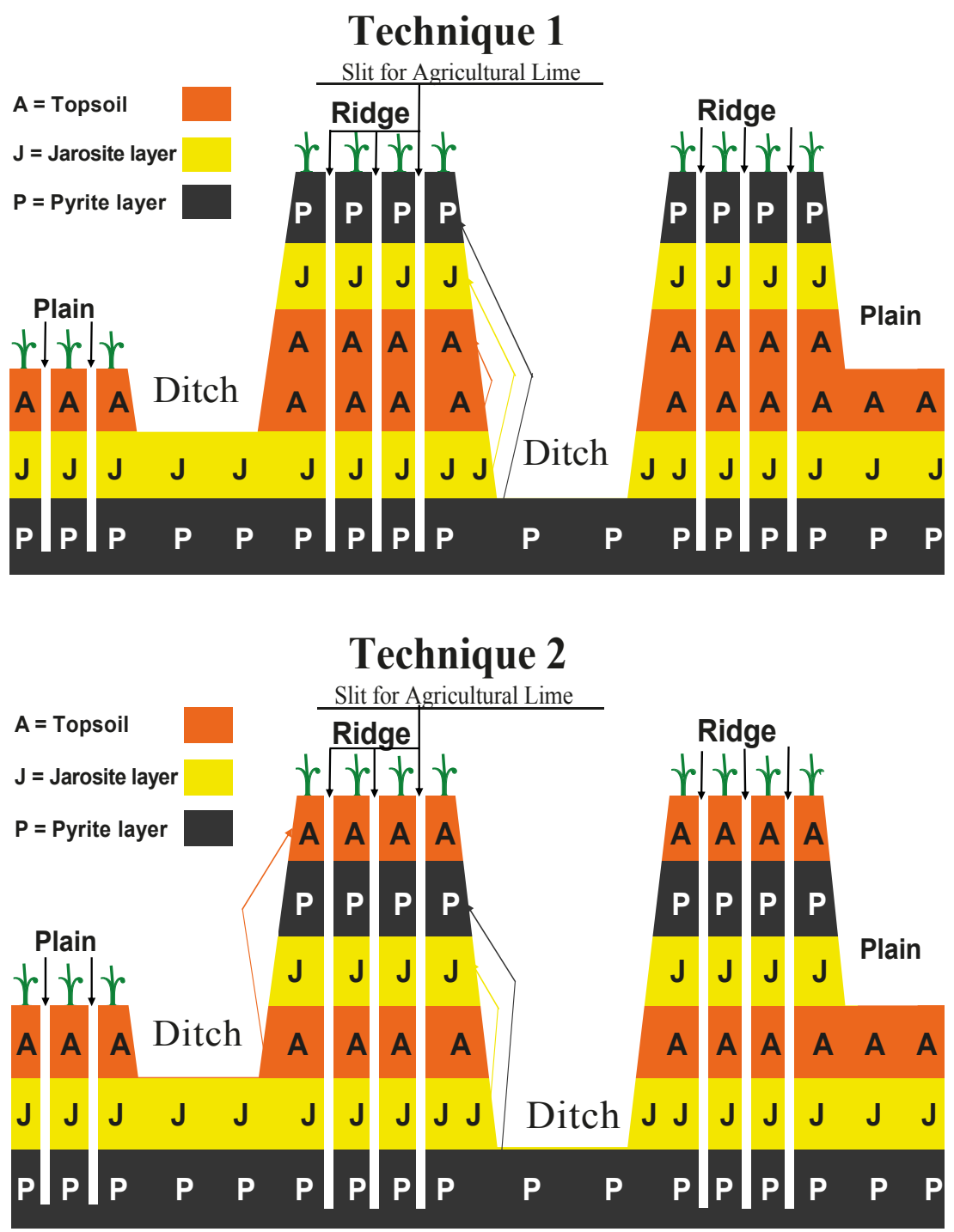

Fig. 2. Nutrition of rice as influenced by Modified-Plain-Ridge-Ditch techniques used in the field experiment for the reclamation of acid sulfate soil.

The post harvested soil data (Fig. 3) of pH, exchangeable $\mathrm{K}^{+}$, $\mathrm{Ca}^{2+}, \mathrm{Mg}^{2+}, \mathrm{Fe}^{3+}$ and $\mathrm{Al}^{3+}$ contents were found to be affected significantly $(\mathrm{p} \leq 0.05)$ by the application of basic slag and aggregate size treatments in different techniques. The application of $\mathrm{A}_{20} \mathrm{BS}_{30}$ attained the highest value of soil $\mathrm{pH}$ of 5.6 in the ridges of Tech 1 and 5.8 in the ridges of Tech 2 during post harvesting followed by the $\mathrm{A}_{20} \mathrm{BS}_{20}(\mathrm{pH} 5.2$ in the ridges of Tech 1 and 5.3 in the ridges of Tech 2: Fig. 3) treatment. The lowest soil $\mathrm{pH}$ of 3.4 was recorded by the control treatment (where there was no exercise of A, BS and techniques). The contents of exchangeable $\mathrm{Al}^{3+}$ and $\mathrm{Fe}^{3+}$ during post harvesting were found to decrease sharply by the treatments and the decrements were more pronounced in the soil of the ridges of the techniques (Fig. 3). The highest amount of exchangeable $\mathrm{Al}^{3+}$ of $7.91 \mathrm{c} \mathrm{mol} \mathrm{kg}^{-1}$ was recorded for the control plots, while this value was decreased to 0.18 for Tech 1 and 0.11 for Tech 2 by the $\mathrm{A}_{20} \mathrm{BS}_{30}$ preceded by the $\mathrm{A}_{30} \mathrm{BS}_{30}$ and $\mathrm{A}_{20} \mathrm{BS}_{20}$ treatments. The decrement was more pronounced with the Tech 2 . Among the treatments, the application of BS ranked first followed by the aggregate size treatments and techniques for the increments of soil $\mathrm{pH}$ and nutrient status of the soil which might be due to basic nature of BS (pH 9.6) as well as its release of some elements mainly $\mathrm{Ca}, \mathrm{Mg}$, etc. into the soils. The results are agreed well with the findings of some researchers. Of them, Khan (2002) reported that the acid sulfate soils released a very large amount of $\mathrm{Al}$, e.g. $10 \mathrm{mM} \mathrm{L}^{-1}$. But a very low concentration of $\mathrm{Al}$ can be hazardous. Concentrations of 1 to $2 \mathrm{mM} \mathrm{Al} \mathrm{L}^{-1}$ 

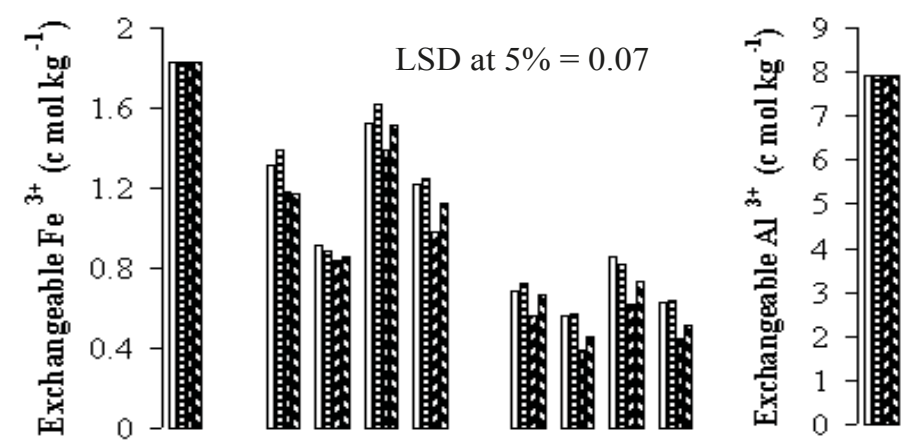

$\square \operatorname{Tech} 1$ BR 14

Đ Tech 1 Piram

$\square$ Tech 2 BR 14

$\mathbf{\Delta T e c h 2 ~ P i z a m ~}$

LSD at $5 \%=0.04$

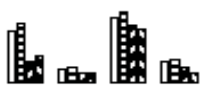

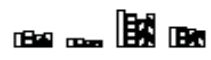
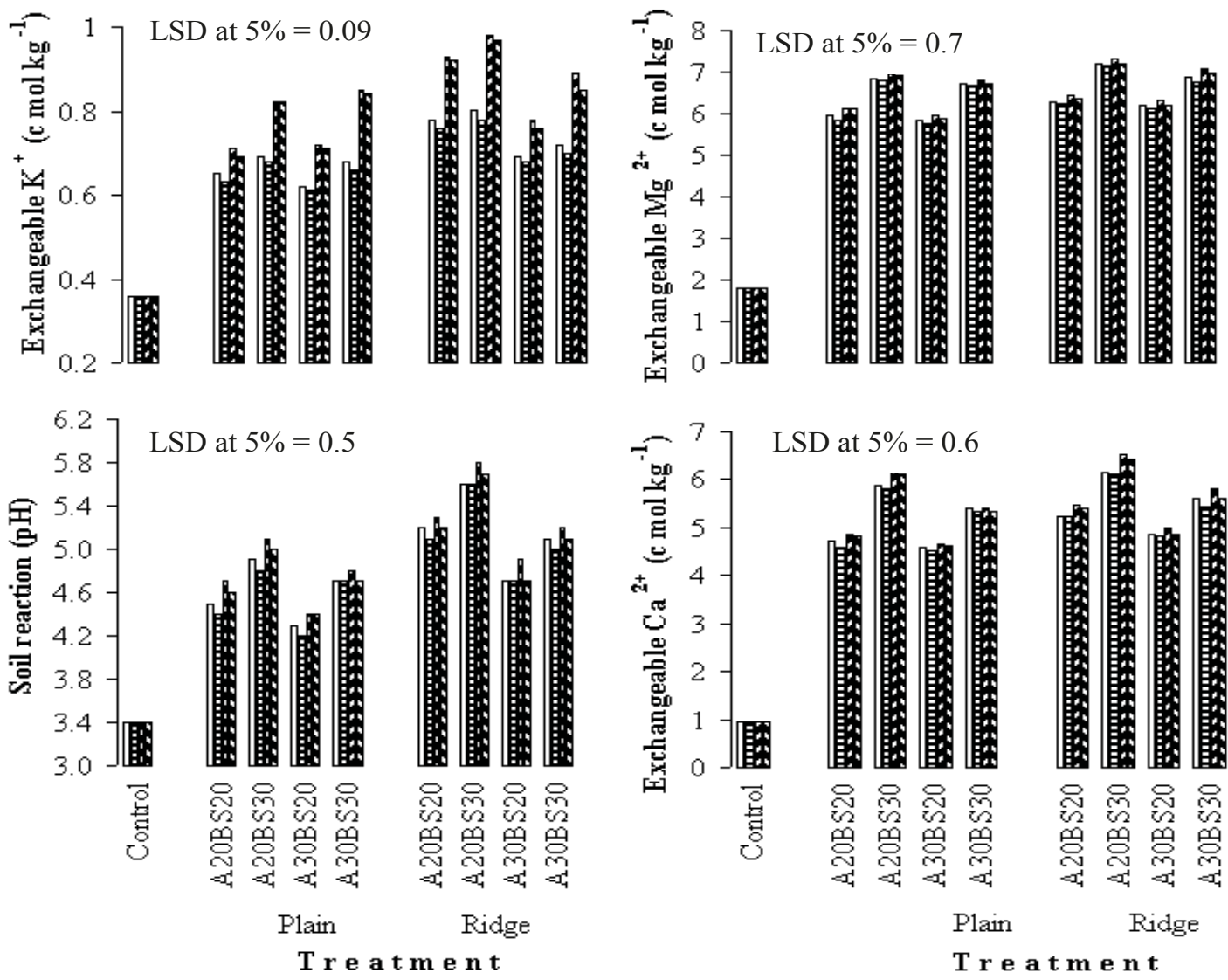

Fig. 3. Consequences of the techniques, basic slag (BS) and aggregate size (A) treatments on some selected properties of acid sulfate soil studied under field condition.

are toxic to most crops and about $2 \mathrm{mM} \mathrm{Al} \mathrm{L}^{-1}$ is toxic for rice. Fishes are most susceptible, fish kills occur at $0.5 \mathrm{mM}$ $\mathrm{Al} \mathrm{L}{ }^{-1}$. Standards and potable water mostly range from 5 to $1450 \mu \mathrm{g} \mathrm{Al} \mathrm{L}^{-1}$ (2 x 10-4 to $6 \times 10^{-2}$ mol Al m${ }^{-3}$ : Sittig, 1994). Khan et al. (2006) reported that the application of BS in ASSs significantly increased soil $\mathrm{pH}, \mathrm{Ca}$ and $\mathrm{Mg}$ with an associated decrease in $\mathrm{Na}, \mathrm{Fe}$ and $\mathrm{Al}$ concentrations over time. However, it was reported that the increase in $\mathrm{pH}$ by the application of slag fertilizer caused the decrease in Eh (Ponnamperuma et al., 1967; Nozoe et al., 1999). But the studied site is in a coastal belt, which receives daily tides $(0.2$ to $0.6 \mathrm{~m}$ high) more than 180 times a year. Therefore, the chance of decrease in Eh and its associated problems might be less for this study area.

Mineral nutrition of rice

\section{Nitrogen, phosphorus, and potassium}

The local Pizam exhibited the best responses on N, P, and K contents in rice shoot at maturity under the Tech 2. As 
expected, the lowest contents of these nutrients in both the rice plants were recorded in the control treatment (Table II). The highest N, P, and K contents in both the BR 14 and Pizam rice plants were mostly obtained in the $\mathrm{A}_{20} \mathrm{BS}_{30}$ followed by $\mathrm{A}_{20} \mathrm{BS}_{20} \geq \mathrm{A}_{30} \mathrm{BS}_{30}$ treatments under Tech 1 and Tech 2 (Table II). These increments were more pronounced with the rice grown on the ridges of both the techniques. The application of basic slag and aggregate size treatments in different techniques significantly $(\mathrm{p} \leq 0.05)$ increased the contents of these nutrients in rice shoot presumably due to reduced soil acidity and salinity as well as the release of $\mathrm{N}$, P, etc. by microbial decomposition and associated soil chemistry with the treatments. Nitrogen $(\mathrm{r}=0.94 * *, 0.97 * *$ for BR 14 and $0.95^{* *}, 0.96^{* *}$ for Pizam in Tech 1 and Tech 2, respectively), phosphorus $\left(\mathrm{r}=0.86^{* *}, 0.97 * *\right.$ for BR 14 and $0.94 * *, 0.96 * *$ for Pizam), and potassium ( $\mathrm{r}=0.94 * *, 0.99 * * \mathrm{BR} 14 ; 0.95 * *$, $0.96^{* *}$ Pizam) contents in both the rice shoot at maturity showed significant positive relationships with the grain yields of these rice cultivars.

\section{Calcium, magnesium and sulfur}

The $\mathrm{Ca}$ and $\mathrm{Mg}$ contents in the rice shoots increased significantly by the application of basic slag and aggregate size treatments in different techniques that created a favorable environment for the uptakes of the nutrients by the rice plants. The lowest contents of $\mathrm{Ca}$ and $\mathrm{Mg}$ in both the rice plant tissues were recorded in the control treatment (Table II). Sulfur content during maturity of both the rice plants grown in the control plots was high (2.0-2.3 $\left.\mathrm{g} \mathrm{kg}^{-1}\right)$ and above the critical $\mathrm{S}$ content $\left(0.6 \mathrm{~g} \mathrm{~kg}^{-1}\right.$, Yoshida and Chaudhry, 1979). However, the $S$ content in the rice shoots significantly $(p \leq 0.01)$ decreased by the application of basic slag and aggregate size treatments in different techniques. The $\mathrm{A}_{20} \mathrm{BS}_{30}$ treatment was recorded for the maximum decrement of the $\mathrm{S}$ content in both rice cultivars grown on the soil of the ridges under both the techniques (Table II). The $\mathrm{S}$ content in both the rice shoots showed a significant $(\mathrm{p} \leq 0.01)$ negative relationship, while $\mathrm{Ca}$ and $\mathrm{Mg}$ contents showed a significant $(\mathrm{p} \leq 0.01)$ positive relationship with the grain yields of both the rice grown under the different techniques. The $\mathrm{S}$ content in the rice shoot was high due to the high concentration of sulfate (Table I) in the growing media and did not show a positive relationship in grain production.

\section{Conclusion}

It is concluded that the application of $\mathrm{BS}_{20}$ ranked first, followed by the $A_{20}>A_{30}$ for the reclamation and improvement of the acid sulfate soil. The significant $(\mathrm{p} \leq 0.05)$ positive improvements on the nutrition of rice and soil properties were more pronounced under Tech 2 than those of Tech 1 under the modified-plain-ridge-ditch system. Application of basic slag and aggregate size treatments in different techniques not only increased soil $\mathrm{pH}$, but also improved the ionic balance between $\mathrm{Ca}$ and $\mathrm{Mg}$, and remarkably decreased the $\mathrm{Fe}$ and $\mathrm{Al}$ contents in the soil and plants.

The application of basic slag in the ASS was an effective measure and was also available at a reasonable price, which not only enabled reclaiming the soil and but also improved the nutrition of rice to optimum level. Moreover, the modified-plain-ridge-ditch techniques and the use of different sizes of aggregates contributed for the physico-chemical amendments of the soil as well as improved the ionic balance among the nutrition of rice. The local variety (Pizam rice) showed better response on the nutrition of rice than that of the high yielding BR 14 rice cultivar grown in the soil. However, for a cost benefit analysis of these treatments in relation to acid neutralizing capacity in different fields for a long time, further studies on different soils and crops under variable climatic conditions should be carried out.

\section{Acknowledgement}

The present research work was carried out by the financial and technical support of the Volkswagen and the Alexander von Humboldt foundations, respectively. The researchers and co-workers of the project are also gratefully acknowledged.

\section{References}

Black CA (1965), Methods of Soil Analysis, Am Soc. Agron. Inst. Publ., Madison, WI, Part 2, Series 9, pp 894-1372,

Chapman HD (1965), Cation exchange capacity In: Methods of Soil Analysis. Part 2, Agron. Series 9, Ed. Black CA, Am. Soc. Agron. Publ., Madison, WI, USA, pp 891-900

Day PR (1965), Particle fractionation and particle size analysis In: Methods of Soil Analysis. Part 2, Agron. Series 9, Ed. Black CA, Am. Soc. Agron. Publ., Madison, WI, USA, pp 545-566.

Dent D (1986), Acid sulfate soils: a baseline for research and development, ILRI Publ., 39 Wageningen, The Netherlands.

Dent DL and Mensvoort MEF (1993), Selected Papers of the Ho Chi Minh City Symposium on Acid Sulfate Soils, ILRI Publ., 53 Wageningen, The Netherlands.

Dost H and van Breemen N (1982), Proceedings of the Bangkok symposium on acid sulfate soils, ILRI Publ., 31 Wageningen, The Netherlands.

Hesse PR (1971), A text Book of Soil Chemical Analysis, John Murry Publ., London, pp 106-234. 
Jackson ML (1973), Soil Chemical Analysis, Prentice Hall of India Pvt. Ltd., New Delhi, pp 67-241.

Khan HR, Bhuiyan MMA, Kabir SM, Blume H-P, Oki Y and Adachi T (2007), Consequences of basic slag on soil $\mathrm{pH}$, calcium and magnesium status in acid sulfate soils under various water contents, J. of Biol. Sci. 7(6): 896-903.

Khan HR, Bhuiyan MMA, Kabir SM, Oki Y and Adachi T (2006), Effects of selected treatments on the production of rice in acid sulfate soils in a simulation study, Jpn. J. Trop. Agr. 50(3): 109-115.

Khan HR (2002), Abatement of environmental problems arising from acid sulfate soils In: Bangladesh environment 2002, Ed. Ahmed MF, Publ. BAPA 2: 950-963.

Khan HR, Bhuiyan MMA, Kabir SM, Ahmed F, Syeed SMA and Blume H-P (2002), The assessment and management of acid sulfate soils in Bangladesh in relation to crop production In: The restoration and management of derelict land: Modern approaches, Eds. Wong MH and Bradshaw AD, pp 254-263.

Khan HR (2000), Problem, prospects and future directions of acid sulfate soils. In Proc. Inter. Conference on Remade Lands 2000, Eds. A Brion and RW Bell. Nov. Perth, Australia, pp 66-67.

Khan HR and Adachi T (1999), Effects of selected natural factors on soil $\mathrm{pH}$ and element dynamics studied in columns of pyretic sediments, Soil Sci. Plant Nutr. 45: 783-793.

Khan HR, Rahman S, Hussain MS and Blume H-P (1996), Response of rice to basic slag, lime and leaching in two saline-acid sulfate soils in pot experiments, $Z$. Pflanzenernahr. Bodenk (J. Plant Nutr. Soil Sci.) 159: 549-555.

Khan HR, Rahman S, Hussain MS and Adachi T (1994), Growth and yield response of rice to selected amendments in an acid sulfate soil, Soil Sci. Plant Nutr. 40: 231-242.

Nelson DW and Sommers LE (1982), Total carbon, organic carbon and organic matter In: Methods of Soil Analysis. Part 2, Agron. Series 9, Ed., Page AL, Am. Soc. Agron. Publ., Madison, WI, USA, pp 539-579,

Nozoe T, Nishibata Y, Sekiguchi T and Inoue T (1999), Effects of the addition of Fe-containing slag fertilizers on the change in Eh in paddy soil, Soil Sci. Plant Nutr. 45: 729-735.
Olsen SR, Cale CV, Watanabe FS and Dean LA (1954), Estimation of available phosphorus in soils by extraction with sodium bicarbonate, USDA Circ. 939, Washington, USA.

Ponnamperuma FN, Tianco EM, Loy T (1967), Redox equilibrium in flooded soils: I. The iron hydroxide systems, Soil Sci. 103: 374-382.

Richards LA (1954), Diagnosis and improvement of saline and alkali soils In: USDA Handbook No. 60. US Govt. Print. Office, Washington, USA, pp 84-156.

Sittig JP (1994), World-wide limits for toxic and hazardous chemicals in air, water and soil, Noyes publication, Peak Ridge, NJ.

Thomas GW (1982), Exchangeable cations In: Methods of Soil Analysis. Part 2, Agron. Series 9. Ed. Page AL, Am. Soc. Agron. Publ., Madison, WI, USA, pp 159-165.

Van Breemen N (1993), Environmental aspects of acid sulfate soils In: Selected Papers of the Ho Chi Minh City Symposium on Acid Sulfate Soils, Eds. Dent DL and van Mensvoort MEF, ILRI Publ., 53: 391-402.

Van Mensvoort MEF and Dent DL (1998), Acid sulfate soils: Methods for assessment of Soil degradation In: Advances in Soil Science, Ed. Lal R, CRC press LLC, Florida, pp 301-335

Yoshida S and Chaudhry MR (1979), Sulfur nutrition of rice. Soil Sci. Plant Nutr. 25: 121-134.

Zaman SMH, Rahman K and Howlader M (1982), Simple lessons from biometry, Publ. No. 54, Bangladesh Rice Research Institute, Gazipur, Bangladesh.

Received: 23 October 2016; Revised: 8 December 2016; Accepted: 28 December 2016. 